\title{
Understanding the Entrepreneurial Intention in the Light of Contextual Factors: Gender Analysis
}

\author{
Md. Atikur RAHAMAN', Md. Julfikar ALI' ${ }^{2}$, Zahidur Rahman MAMOON ${ }^{3}$, Ahmed Al ASHEQ ${ }^{4}$
}

Received: July 03, 2020 Revised: July 28, 2020 Accepted: August 10, 2020

\begin{abstract}
Entrepreneurial intention is receiving immense recognition in entrepreneurship researches, as it motives an individual to become an entrepreneur. Still, the interplay between gender perspective and contextual factors (i.e., access to capital, business information, social network, educational support, structural support) are not fully investigated in understanding the entrepreneurial intention in developing countries like Bangladesh. Therefore, the paper aims to examine the gender difference and educational discipline difference in the university's students' entrepreneurial intention in relation to contextual factors in Bangladesh. In this study, sample has been particularly taken from the different disciplinary students of private universities. Five-point Likert scale-based survey questionnaire was developed based on past researches. 280 online survey forms were distributed among the university students and finally 225 students' response were found correct as the study sample size (final survey response rate $=80 \%$ ), after eliminating the incorrect survey responses. For statistical analysis SPSS 23.0 version is used. One-way ANOVA is used to measure the gender and discipline difference on entrepreneurial intention among male and female students. The results show that business information and social network will have more influence on male students' entrepreneurial intention, and comparatively, business students have more willingness to become entrepreneurs than other departmental students.
\end{abstract}

Keywords: Entrepreneurial Intention, Gender, Business Information, Social Networks, Bangladesh

JEL Classification Code: M10, M13, M21

\section{Introduction}

Encouragement of entrepreneurship is a nationwide priority for many governments worldwide, especially for the developing nations as entrepreneurship has a positive impact on a country's economic development and its ability to create job opportunities. Up to now, most researches on encouraging entrepreneurship has been conducted for

${ }^{1}$ First Author. Associate Professor, School of Economics \& Management, Jiujiang University, Jiangxi, China. E-mail: atik@jju.edu.cn

${ }^{2}$ Associate Professor, Department of Business Administration, The International University of Scholars (IUS), Bangladesh.

E-mail: jalidhaka2020@gmail.com

${ }^{3}$ Senior Lecturer, Department of Business Administration, Eminence College Uttara, Dhaka, Bangladesh. E-mail: zrm347@gmail.com

${ }^{4}$ Corresponding Author. Lecturer, World School of Business, World

University of Bangladesh, Bangladesh [Postal Address: Dhanmondi,

Dhaka 1205, Bangladesh] E-mail: aasheq@business.wub.edu.bd

(c) Copyright: The Author(s)

This is an Open Access article distributed under the terms of the Creative Commons Attribution Non-Commercial License (https://creativecommons.org/licenses/by-nc/4.0/) which permits unrestricted non-commercial use, distribution, and reproduction in any medium, provided the original work is properly cited. developed countries, hence, there is not much information on the same matter for developing countries (Bruton, Ahlstrom, \& Obloj, 2008) and information on entrepreneurship in economies that are developed may differ from that of economies that are growing in terms of application (Bruton et al., 2008). Researchers in the field of entrepreneurship essentially exhibited that entrepreneurial functions and their determinants are triggered by different dimensional aspects of socio-cultural and political circumstances, which would vary remarkably across various nations, and it would limit the applicability of the research findings of developed economies to developing economies (Bruton et al., 2008).

Ever since the 1980s, entrepreneurship has received much attention. It has been regarded as a driving factor for the growth of social and economic matters by building novel opportunities for employment and supplying goods/ services to the people (Wennekers et al., 2005) and work as an antidote for issues namely, high inflation and high unemployment (Wennekers \& Thurik, 1999). The real and possible entrepreneurs have been provided with support through diverse range or trainings and finances by the governments and NGOs. Entrepreneurship departments or at 
the minimum, entrepreneurship courses have started opening at a lot of universities to encourage entrepreneurship among people. Students that are currently enrolled in undergraduate/ postgraduate programs, could be potential candidate of initiating entrepreneurial activities. Several studies have been conducted on the effect of personal characteristics or contextual factors on entrepreneurial intention (EI). Personal characteristics are more difficult to influence EI rather than contextual factors according to educators and also to the makers of making decisions and policies.

Even though Bangladesh's GDP growth has been increasing for the last couple of years (Akter et al., 2020), but unemployment has become a matter of concern for the policy makers. In Bangladesh, a substantial part of the jobless people are university graduates. Entrepreneurship plays a pivotal role in generating jobs and encouragement of entrepreneurial activities can possibly be a remedial solution to unemployment problem (Barba-Sánchez \& AtienzaSahuquillo, 2018). Entrepreneurship has been believed to be as one of the vital components that can practically enable the creation of jobs and welfare growth (Korent, Vuković, \& Brčić, 2015), and entrepreneurs are recognized as advocates of the positive growth by generating the effective projects through commencing creative and new concepts (Türker \& Selcuk, 2009). Furthermore, a vital part in progressing a country's economic growth is played by entrepreneurial activities (Ezeh, Nkamnebe, \& Omodafe, 2019). Essentially, entrepreneurship is found as a desirable choice of profession among students, and the upcoming generation has been voicing a proclivity for being their own bosses around the world (Wang, Lu, \& Millington, 2011).

Lately, considerable attention is ascribed to entrepreneurial intention. EI is considered as the primary stage of entrepreneurship development that reveals a person's enthusiasm in starting an entrepreneurial project (Nowiński \& Haddoud, 2019). Thus, it is crucial to study and investigate the EI that might possibly strengthen entrepreneurship (Al-Jubari, Hassan, \& Liñán, 2018). This condition inspires the authors of this study to inquire into the Bangladeshi university students' entrepreneurial intention (EI) to deliver the tactical suggestions for the faculty members of universities and makers of policy of the country with the aim that they could enable entrepreneurial activities among graduate students to put up a fight against the escalating unemployment problem. Hence, it can be surmised that the students' intention would be a typical example to scrutinize the entrepreneurial intention (EI). As entrepreneurship is established as among the prompt professional preference by the students who just graduated and therefore it is pertinent to scrutinize the factors that arouses students' intention to become an entrepreneur (Nguyen, 2018).

On the other hand, according to the institutional economic theory (North, 2005), factors pertaining to the environment or backgrounds may be expected to play a significant part in understanding the entrepreneurship. Generally, entrepreneurial purposes, processes and developmental mechanism can largely be explained and advanced by contextual factors (Lüthje \& Franke, 2003). Still, the roles played by contextual factors in forming new businesses has received diminutive attention, precisely in developing countries. A small number of investigative studies have been observed regarding the comparative contributions of the contextual influences to the creation of new businesses in developing countries (Karimi et al., 2017). Importantly, till date entrepreneurial intention (EI) related studies have focused on personality traits factors, individual factors, demographic factors, whereas very few studies considered contextual factors separately to detect entrepreneurial intention. Although several studies measured the gender difference on different factors of entrepreneurship (Yukongdi \& Lopa, 2017); still the interplay between gender difference, entrepreneurial intention and contextual factors has remained merely investigated, especially in Bangladesh context. Thus, the study aims to identify whether does any gender difference on entrepreneurial intention (EI) of Bangladeshi students in terms of contextual factors exist or not. Another objective of the study is to find out the university's educational discipline difference on the contextual determinant factors of students' EI.

\section{Literature Review}

\subsection{Entrepreneurship and Entrepreneurial Intention (EI)}

Entrepreneurship is not only merely about developing business plans and setting them up, but also a method of reasoning and taking necessary actions pertinent to each segment of financial, societal and ecological system of the entire surroundings environment (Wilson et al., 2009). Entrepreneurship can be perceived as an activity which includes scrutiny and leverage of untapped opportunities to launch novel products or services, which are new to business market (Shane, 2003). Entrepreneurial intention (EI) induces the introduction of a new business and works as an outstanding forecaster for producing prospective and promising entrepreneurs (Mcleod \& Thomson, 2009). The research of Ajzen et al. (2009) and Manolova, Brush and Edelman (2008) discovered an extraordinary and favorable association between EI and entrepreneurial outcomes, even though the propensity of coming up with a new business does not guarantee the formation of a new venture. Entrepreneurial behavior may be distinguished as planned actions that are performed with a deliberate purpose to a distinct entrepreneurial activity, such as introducing a new venture or launching a new business product or service (Mair 
\& Noboa, 2006). Entrepreneurial intention (EI) is illustrated as an individual's intended desire to certain upcoming way of behaving that is designed to begin with a business or an organization (Krueger \& Brazeal, 1994). Moreover, entrepreneurial intention (EI) point outs the inclination or likelihood of a person to initiate and begin a new business venture (Bui et al., 2020) and EI is considered as a crucial tendency for development and formation of new enterprises (Luc, 2020). EI has been studied as a purpose of assessing the authentic entrepreneurial behavior (Luc, 2018).

\subsection{Contextual Factors}

There are several research studies that have investigated how entrepreneurial intention (EI) is influenced by contextual factors. Hence, the significance of contextual factors must not be overlooked in the studies of entrepreneurship, despite the fact that most of the studies concentrate on heredity and individual characteristics claims (Türker \& Selçuk, 2009). Individual characteristics and contextual factors were discovered to exert immense influences on entrepreneurial intention (EI), which was revealed by the results of Lüthje and Franke (2003)'s research on MIT (Massachusetts Institute of Technology) engineering students. Their result indicates that the contextual factors and situational factors play a noteworthy role in determining entrepreneurial behavior of MIT students. Therefore, the five variables of contextual factors are discussed below in relation of entrepreneurship and EI.

\subsection{Access to Capital}

Undoubtedly, access to capital is amongst the vital influences in setting up a new business (Kim, Aldrich \& Keister, 2006). Numerous researchers have identified that substantial number of individuals have surrendered to their incapability of accessing capital by abandoning their growing entrepreneurial careers (Meier \& Pilgrim, 1994). Personal funds, family, peers, possibly a loan from the bank, or by finding an investor all are considered to be sources of capital accumulation that is essential to initiate a new business (Cetindamar et al., 2012). A study conducted on the entrepreneurial intention (EI) of university students in Turkey, have presented with the findings that the students' primary choice for gathering capital was their personal funds, family's financial support and bank loans (Kutanis, Bayraktaroglu, \& Bozkurt, 2006). Irrespective of gender, monetary resource is a crucial factor for any emerging entrepreneurial actions (Cetindamar et al., 2012).

\subsection{Business Information}

To start a new venture and attain continuous development, it is of utmost importance to have information on business readily available (Kristiansen \& Indarti, 2004). To determine the advantage over competitors, an individual requires details on the market prior to starting a business. By a mental process, the entrepreneurial decision is made, and, throughout this process, market opportunities can be understood only with information that is applicable and precise. Therefore, for an entrepreneurial venture, the ease and convenient accessibility to business information is a fundamental component (Minniti \& Bygrave, 1999). Furthermore, Kristiansen and Indarti (2004) in their research among university students, pointed out a notable and constructive relationship between the students' accessibility of business information and the entrepreneurial intention (EI).

\subsection{Social Networks}

The formation of a new venture is primarily based on the acceleration of an original idea, service, or product that would be the outcome of the thoughtful ambition of an entrepreneur. There might be a shortage in resources for the entrepreneur such money, information on business, but these are essential resources to implement the business idea into existence with facilitating entrance into business market (Sesen, 2013). If the entrepreneurs don't acquire the essential resources, then their dreams of coming into market with their newly developed businesses won't be possible to turn into a reality. Based on this, a fundamental part is played by the social networks in gaining those valuable resources for the businesses. Study results have shown that social networks have a profound influence on a person's EI (Kristiansen \& Indarti, 2004). If an entrepreneur senses that he/she will have access to monetary funds and information on business within their social network, the concept of starting a new business is much more likely to emerge as a reality (Sequeira, Mueller, \& McGee, 2007). Entrepreneurs might become part of various social networks for the continuation of a new business (Huggins, 2000) and strong networks could guarantee the steady flow of capital and information, that could necessarily play a role in reducing business operational difficulty (Kristiansen \& Ryen, 2002). Consequently, social network can be perceived as a tool that has strong influence on a person's willingness to be an entrepreneur (Sequeira et al., 2007).

\subsection{University Education}

Students who perceive their university circumstances as inadequate and adverse to support entrepreneurial activities, may have remarkably decreased willingness to become an entrepreneur than those who find their university environment as positive to inspire entrepreneurship (Franke \& Luthje, 2004). Additionally, a comparative analysis was conducted by Franke and Luthje (2004) based on the 
influence of individual and age, race, and gender factors, and the university context on a person's proclivity to become an entrepreneur and reported that the university context was the most effective variable. Schwarz et al. (2009) found identical findings in arguing that environment of the educational programs has been a driving force of entrepreneurial intention (EI). Likewise, Packham et al. (2010) established that university's entrepreneurship educational programs and curriculum plays a vital role in shaping a person's desire to put his or her carrier choice towards entrepreneurial venture. Furthermore, Smith, Collins and Hannon (2006) suggested that the inclusion and continuation of entrepreneurial education in British universities must be fostered to expedite the speed of entrepreneurial activities among students.

\subsection{Structural Support}

Global Entrepreneurship Monitor (GEM) report emphasizes the significant functions played by culture and institutions that provide favorable conditions to grow and develop entrepreneurial activities. As stated by Davis (2002) which is that several governments are more committed to stimulate entrepreneurship related projects, while not facilitating a convenient mechanism for providing necessary assistance to the entrepreneurial population. Nonetheless, policy frameworks and measures have been enhancing the flexibility of work schedules, business information and ease market entrance while eradicating the different aspects of bureaucracy and speeding up the government paperwork to smoothen the entrepreneurial functions within the ecosystem (Kelley, Singer \& Herrington, 2012). It is claimed that the cultural environment that motivates perseverance and inventiveness in lieu of political influence; and governments which are more concerned with financial aspects rather than political concerns, importantly contribute to the entrepreneurship development (Yurtkoru, Kușcu, \& Doğanay, 2014). As claimed by the research of Türker and Selçuk (2009) that individuals may be inspired to get involved in entrepreneurial activities by the various government institutions and private businesses and NGOS, and structural support has been proven to have positive effect on EI.

\section{Methodology}

The study has been undertaken at few private universities in Bangladesh, from where the current university students were chosen as study sample. Survey questionnaire was carefully developed after reviewing the existing literature. The questionnaire was self-administered by nature for convenience purpose. Non-probability sampling strategy was adopted that was convenient to conduct this research among the students. The questionnaire has two sections: first section encompasses the basic demographic information of the university students and second part incorporates the Likert scale based item wise questions on study variables (i.e., entrepreneurial intention, access to capital, business information, social network, educational support, structural support). Five-point Likert scale was used in this study, in which " 1 " denotes "Strongly Disagree" and "5" denotes "Strongly Agree". The study variables have been mainly adopted from the studies of Sesen (2013) and Yurtkoru et al. (2014). Among the students, 280 survey forms were distributed and finally 225 forms were found fully correct, hence $n=225$ has been kept as sample size in this study. For reliability measures of the variables, Cronbach alpha values $(\alpha)$ of 0.70 is considered as reliable score, which was recommended by Hair et al. (2010) and all the variables were found as reliable (Table 1). SPSS version 23.0 is taken into consideration for the purpose of executing the descriptive statistical analysis, reliability analysis and ANOVA analysis to capture the gender differences.

\section{Results and Discussion}

The study $(\mathrm{n}=225)$ has collected data from the students who are studying different subjects under various disciplines and departments of the Bangladeshi universities. The descriptive statistics (see Table 2) describes that out of 225 students, $136(60 \%)$ students were male and $89(40 \%)$ were female students who took part in this study. In terms of age distribution, 157 (70\%) students belonged to age category of 21 to 30 years, $56(25 \%)$ students were aged in between 31 to 40 years and rest of the students were aged above more than 40 years and on forward. Table 2 also shows that in terms of department, $99(40 \%)$ students were studying in Arts department, 57 (25\%) students were studying in Business department, $31(13 \%)$ students were studying in Science department and 38 students (17\%) were studying in Humanities department. Furthermore, Table 2 also reveals that majority of the sample students, $111(59 \%)$ were studying their $4^{\text {th }}$ year of their bachelor's degree and $88(39 \%)$ were doing their masters/MBA degree. Rest of the students were mainly in their $1^{\text {st }}$ year, $2^{\text {nd }}$ year and $3^{\text {rd }}$ year of their bachelor's degree.

Table 1: Reliability Analysis

\begin{tabular}{|l|c|}
\hline Variables & Cronbach $(\boldsymbol{\alpha})$ Alpha values \\
\hline Entrepreneurial Intention & 0.855 \\
\hline Access to Capital & 0.785 \\
\hline Business Information & 0.859 \\
\hline Social Network & 0.871 \\
\hline Educational Support & 0.760 \\
\hline Structural Support & 0.813 \\
\hline
\end{tabular}


Table 2: Descriptive Statistics

\begin{tabular}{|l|c|c|}
\hline Description & Frequency & Percent \\
\hline Gender & & 60.4 \\
\hline Male & 136 & 39.6 \\
\hline Female & 89 & 20.4 \\
\hline Age & & 26.2 \\
\hline 21 - 23 years & 46 & 23.1 \\
\hline $24-26$ years & 59 & 17.3 \\
\hline 27 - 30 years & 52 & 7.6 \\
\hline 31 - 35 years & 39 & 3.1 \\
\hline $36-40$ years & 17 & 2.2 \\
\hline $41-50$ years & 7 & 44.0 \\
\hline More than 50 years & 5 & 25.3 \\
\hline Discipline & & 13.8 \\
\hline Arts Department & 99 & 16.9 \\
\hline Business Department & 57 & \\
\hline Science Department & 31 & .4 \\
\hline Humanities Department & 38 & 2.7 \\
\hline Year of Education & & 4.9 \\
\hline 1st Year & 1 & 49.3 \\
\hline 2nd year & 6 & 39.1 \\
\hline 3rd year & 11 & 3.6 \\
\hline 4th year & 111 & \\
\hline Master/MBA & 88 & \\
\hline Others & 8 & \\
\hline
\end{tabular}

The study applied the ANOVA analysis to examine the gender difference between male and female students based on entrepreneurial intention, access to capital, business information, social network, educational support and structural support (see Table 3). The ANOVA result reveals there has been a notable difference in relation to the impact of business information on entrepreneurial intention among male and female sample respondents. It is understood from Table 3 that business information has more effect on male students' entrepreneurial intention than that of female students $(\mathrm{F}=5.758, \mathrm{p}=0.017)$.

Also, social network is found to have more influence on male students' entrepreneurial intention than that of female students $(\mathrm{F}=5.951, \mathrm{p}=0.015)$ (see Table 3$)$. It does nesseciate that if the male students will have access to business related information and if they receive more support from their family, frineds, neighbours and social community, they will mostly be infleucned to start their new entrepreneurial business. However, no remarkable differences were noticed between the male and female students in respect to their entrepreneruial intention, access to capital, educational support and structural support. The result is consistent with Yukongdi and Lopa (2017) as they reported no difference in entrepreneurial intention among male and female students.

The study has also applied ANOVA analysis to test the possible difference among the university students' discipline on their entrepreneurial intention (see Table 4). The result shows that students of business department will have better intention on entrepreneurship than other disciplinary students $(F=3.011, p=0.031)$. It can easily be perceived that since business department offers different business and entrepreneruship development related courses to the students; hence the students of Business department will have more willingness to be an entrepreneur than other departmental students. The finding is macthed with the study of Gerba (2012), who found that Business students have more entrepreneurial intention than Engineering students. 
Table 3: One-way ANOVA tests on Gender

\begin{tabular}{|c|c|c|c|c|c|}
\hline Variables & Gender & $\mathbf{N}$ & Mean & F-value & $p$-value \\
\hline \multirow[t]{2}{*}{ Entrepreneurial Intention } & Male & 136 & 3.6691 & \multirow{2}{*}{.838} & \multirow{2}{*}{0.361} \\
\hline & Female & 89 & 3.5930 & & \\
\hline \multirow[t]{2}{*}{ Access to Capital } & Male & 136 & 3.6066 & \multirow{2}{*}{.309} & \multirow{2}{*}{0.579} \\
\hline & Female & 89 & 3.5581 & & \\
\hline \multirow[t]{2}{*}{ Business Information } & Male & 136 & 3.6535 & \multirow{2}{*}{5.758} & \multirow{2}{*}{$0.017^{*}$} \\
\hline & Female & 89 & 3.4382 & & \\
\hline \multirow[t]{2}{*}{ Social Network } & Male & 136 & 3.6958 & \multirow{2}{*}{5.951} & \multirow{2}{*}{$0.015^{*}$} \\
\hline & Female & 89 & 3.4817 & & \\
\hline \multirow[t]{2}{*}{ Educational Support } & Male & 136 & 3.6287 & \multirow{2}{*}{.270} & \multirow{2}{*}{0.604} \\
\hline & Female & 89 & 3.5787 & & \\
\hline \multirow[t]{2}{*}{ Structural Support } & Male & 136 & 3.6605 & \multirow{2}{*}{.908} & \multirow{2}{*}{0.342} \\
\hline & Female & 89 & 3.5824 & & \\
\hline
\end{tabular}

Note: * variable is significant at the 0.05 level and ${ }^{* *}$ variable is at the 0.01 level ( 2 tailed)

Table 4: One-way ANOVA tests on Educational Discipline

\begin{tabular}{|c|c|c|c|c|c|}
\hline Variables & Discipline & $\mathbf{N}$ & Mean & F-value & $p$-value \\
\hline \multirow[t]{4}{*}{ Entrepreneurial Intention } & Arts Department & 99 & 3.6801 & \multirow{4}{*}{3.011} & \multirow{4}{*}{$0.031^{*}$} \\
\hline & Business Department & 57 & 3.7700 & & \\
\hline & Science Department & 31 & 3.5305 & & \\
\hline & Humanities Department & 38 & 3.4240 & & \\
\hline \multirow[t]{4}{*}{ Access to Capital } & Arts Department & 99 & 3.7121 & \multirow{4}{*}{9.020} & \multirow{4}{*}{$0.000^{* *}$} \\
\hline & Business Department & 57 & 3.7310 & & \\
\hline & Science Department & 31 & 3.4355 & & \\
\hline & Humanities Department & 38 & 3.1711 & & \\
\hline \multirow[t]{4}{*}{ Business Information } & Arts Department & 99 & 3.6578 & \multirow{4}{*}{3.612} & \multirow{4}{*}{$0.014^{*}$} \\
\hline & Business Department & 57 & 3.6184 & & \\
\hline & Science Department & 31 & 3.5726 & & \\
\hline & Humanities Department & 38 & 3.2566 & & \\
\hline \multirow[t]{4}{*}{ Social Network } & Arts Department & 99 & 3.6250 & \multirow{4}{*}{3.905} & \multirow{4}{*}{$0.010^{*}$} \\
\hline & Business Department & 57 & 3.7544 & & \\
\hline & Science Department & 31 & 3.6734 & & \\
\hline & Humanities Department & 38 & 3.3092 & & \\
\hline \multirow[t]{4}{*}{ Educational Support } & Arts Department & 99 & 3.6742 & \multirow{4}{*}{2.640} & \multirow{4}{*}{0.050} \\
\hline & Business Department & 57 & 3.7237 & & \\
\hline & Science Department & 31 & 3.4839 & & \\
\hline & Humanities Department & 38 & 3.3684 & & \\
\hline \multirow[t]{4}{*}{ Structural Support } & Arts Department & 99 & 3.6700 & \multirow{4}{*}{3.048} & \multirow{4}{*}{$0.030^{*}$} \\
\hline & Business Department & 57 & 3.7602 & & \\
\hline & Science Department & 31 & 3.5215 & & \\
\hline & Humanities Department & 38 & 3.4167 & & \\
\hline
\end{tabular}

Note: * variable is significant at the 0.05 level and ${ }^{* *}$ variable is at the 0.01 level (2 tailed) 
Table 4 also describes that access to capital $(\mathrm{F}=9.020, \mathrm{p}=$ $0.000)$, business information $(\mathrm{F}=3.612, \mathrm{p}=0.014)$, social network $(\mathrm{F}=3.905, \mathrm{p}=0.010)$ and structural support $(\mathrm{F}=$ $3.048, \mathrm{p}=0.030$ ) have more infleucne on the entrepreneurial inetntion of Business department's students than other disciplinary students.

\section{Conclusions}

The overall aim of the study is to examine gender difference and educational discipline difference on university students' intention on starting entrepreneurial business based on contextual variables such as, access to capital, business information, social network, educational support, structural support in Bangladesh. The findings suggest that business information and social network will be more influential to impact male students' intention to start their own entrepreneurial ventures. Hence, universities need to build mutual relationship with business research centers, industry experts and representatives of the business firms to share their current views and future projection on business dynamics, with guiding students with relevant and necessary business information.

As a result, they will get opportunity to be linked with business industry analysts and corporate people. To increase student's network, universities might be interested into providing such type of course assignments where corporate leaders will be invited to judge student's presentation, in this way students will get chance to showcase their talent in front of the corporate officials and could make networking with corporate officials. Furthermore, more idea generation and innovation related training and competitions can be arranged among different disciplinary students at universities, through which new social networks will be created for the students, which could be helpful for them in driving their intention towards new business venture formation. The study also reveals that business students have more EI than that other disciplinary students. Therefore, it might be suggestive that faculty members of Art \& Humanities and Science department may consider the inclusion of entrepreneurship coursework and entrepreneurial training programs in their curriculum to induce students' entrepreneurial intention.

\section{References}

Ajzen, I., Csasch, C., \& Flood, M. G. (2009). From intentions to behavior: implementation intention, commitment, and conscientiousness. Journal of Applied Social Psychology, 39(6), 1356-1372.
Akter, S., Ali, M. H., Abedin, M. T., \& Hossain, B. (2020). Directors' Remuneration and Performance: Evidence from the Textile Sector of Bangladesh. Journal of Asian Finance, Economics, and Business, 7(6), 265-275. https://doi.org/10.13106/ jafeb.2020.vol7.no6.265

Al-Jubari, I., Hassan, A., \& Liñán, F. (2019). Entrepreneurial intention among University students in Malaysia: integrating self-determination theory and the theory of planned behavior. International Entrepreneurship and Management Journal, 15(4), 1323-1342.

Barba-Sánchez, V., \& Atienza- Sahuquillo, C. (2018). Entrepreneurial intention among engineering students: The role of entrepreneurship education. European Research on Management and Business Economics, 24(1), 53-61.

Bruton, G. D., Ahlstrom, D., \& Obloj, K. (2008). Entrepreneurship in emerging economies: Where are we today and where should the research go in the future. Entrepreneurship: Theory and Practice, 32(1), 1-14.

Bui, T. H. V., Nguyen, T. L. T., Tran, M. D., \& Nguyen, T. A. T. (2020). Determinants Influencing Entrepreneurial Intention among Undergraduates in Universities of Vietnam. Journal of Asian Finance, Economics and Business, 7(7), 369-378. https:// doi.org/10.13106/jafeb.2020.vol7.no7.369

Cetindamar, D., Gupta, V. K., Karadeniz, E. E., \& Egrican, N. (2012). What the numbers tell: the impact of human, family and financial capital on women and men's entry into entrepreneurship in Turkey? Entrepreneurship \& Regional Development, 24(1/2), 29-51.

Davis, S. (2002). Social entrepreneurship: Towards an entrepreneurial culture for social and economic development. The Youth Employment Summit, Alexandria, Egypt, September 7-11.

Ezeh, P. C., Nkamnebe,A. D., \& Omodafe,U.P.(2019). Determinants of entrepreneurial intention among undergraduates in a Muslim community. Management Research Review. [Online First]. https://doi. org/10.1108/MRR-09-2018-0348

Franke, N., \& Luthje, C. (2004). Entrepreneurial intentions of business students: a benchmarking study. International Journal of Innovation and Technology Management, 1(3), 269-288.

Gerba, D. T. (2012). Impact of entrepreneurship education on entrepreneurial intentions of business and engineering students in Ethiopia. African Journal of Economic and Management Studies, 3(2), 258-277.

Hair, J. F., Black, W. C., Babin, B. J., \& Anderson, R. E. (2010). Multivariate Data Analysis. Upper Saddle River, NJ: Pearson Prentice Hall.

Huggins, R. (2000). The success and failure of policy-implanted inter-firm network initiatives: motivations, processes and structure. Entrepreneurship and Regional Development, 12(2), 211-236. 
Karimi, S., Biemans, H. J., Naderi Mahdei, K., Lans, T., Chizari, M., \& Mulder, M. (2017). Testing the relationship between personality characteristics, contextual factors and entrepreneurial intentions in a developing country. International Journal of Psychology, 52(3), 227-240.

Kelley, D. J., Singer, S., \& Herrington, M. (2012). The Global Entrepreneurship Monitor. Wellesley, MA: Babson College.

Kim, P. H., Aldrich, H. E., \& Keister, L. A. (2006). Access (not) denied: the impact of financial, human and cultural capital on entrepreneurial entry in the United States. Small Business Economics, 27(1), 5-22.

Korent, D., Vuković, K., \& Brčić, R. (2015). Entrepreneurial activity and regional development. Economic researchEkonomska istraživanja, 28(1), 939-958.

Kristiansen, S., \& Indarti, N. (2004). Entrepreneurial intention among Indonesian and Norwegian students. Journal of Enterprising Culture, 12(1), 55-78.

Kristiansen, S., \& Ryen, A. (2002). Enacting their business environment: Asian entrepreneurs in East Africa. African and Asian Studies, 1(3), 165-186.

Krueger, N. F., \& Brazeal, D. V. (1994). Entrepreneurial potential and potential entrepreneurs. Entrepreneurship Theory and Practice, 18(3), 91-104.

Kutanis, O. R., Bayraktaroglu, S., \& Bozkurt, O. (2006). Is the personality features important in entrepreneurial orientation and experience? In: The 14th National Management and Organization Congress Proceedings (pp.12-32). Ataturk University, Erzurum, Turkey.

Luc, P. T. (2018). The relationship between perceived access to finance and social entrepreneurship intentions among university students in Vietnam. Journal of Asian Finance, Economics and Business, 5(1), 63-72. http://dx.doi.org/10.13106/jafeb.2018. vol5.no1.63

Luc, P. T. (2020). Outcome Expectations and Social Entrepreneurial Intention: Integration of Planned Behavior and Social Cognitive Career Theory. Journal of Asian Finance, Economics, and Business, 7(6), 399-407. https://doi.org/10.13106/jafeb.2020. vol7.no6.399

Lüthje, C., \& Franke, N. (2003). The 'making' of an entrepreneur: testing a model of entrepreneurial intent among engineering students at MIT. R\&D Management, 33(2), 135-147.

Mair, J., \& Noboa, E. (2006). Social entrepreneurship: How intentions to create a social venture are formed. In: Social entrepreneurship (pp. 121-135). London, UK: Palgrave Macmillan.

Manolova, T. S., Brush, C. G., \& Edelman, L. F. (2008). What do women entrepreneurs want? Strategic Change, 17(4), 69-82.

McLeod, J., \& Thomson, R. (2009). Researching Social Change: Qualitative Approaches. London, UK: Sage Publications.
Meier, R., \& Pilgrim, M. (1994). Policy-induced constraints on small enterprise development in Asian developing countries. Small Enterprise Development, 5(2), 66-78.

Minniti, M., \& Bygrave, W. (1999). The microfoundations of entrepreneurship. Entrepreneurship Theory and Practice, 23(4), 41-52.

Nguyen, C. (2018). Demographic factors, family background and prior self-employment on entrepreneurial intention-Vietnamese business students are different: why?. Journal of Global Entrepreneurship Research, 8(1), 1-17. DOI: 10.1186/s40497018-0097-3

North, D. C. (2005). Understanding the Process of Economic Change. Princeton, NJ: Princeton University Press.

Nowiński, W., \& Haddoud, M. Y. (2019). The role of inspiring role models in enhancing entrepreneurial intention. Journal of Business Research, 96, 183- 193.

Packham, G., Jones, P., Miller, C., Pickernell, D., \& Brychan, T. (2010). Attitudes towards entrepreneurship education: a comparative analysis. Education + Training, 52(8/9), 568-586.

Schwarz, E. J., Wdowiak, M. A., Almer-Jarz, D. A., \& Breitenecker, R.J. (2009). The effects of attitudes and perceived environment conditions on students' entrepreneurial intent. Education+ Training, 51(1), 272-291.

Sequeira, J., Mueller, S. L., \& McGee, J. E. (2007). The influence of social ties and self-efficacy in forming entrepreneurial intentions and motivating nascent behavior. Journal of Developmental Entrepreneurship, 12(3), 275-293.

Sesen, H. (2013). Personality or environment? A comprehensive study on the entrepreneurial intentions of university students. Education + Training, 55(7), 624-640.

Shane, S. (2003). A General Theory of Entrepreneurship: The Individual-Opportunity Nexus. Cheltenham, UK: Edward Elgar.

Smith, A. J., Collins, L. A., \& Hannon, P. D. (2006). Embedding new entrepreneurship programmes in UK higher education institutions: challenges and considerations. Education + Training, 46(8/9), 555-567.

Türker, D., \& Selçuk, S. S. (2009). Which factors affect entrepreneurial intention of university students? Journal of European Industrial Training, 33(2), 142-159.

Wang, W., Lu, W., \& Millington, J. K. (2011). Determinants of entrepreneurial intention among college students in China and USA. Journal of Global Entrepreneurship Research, $1(1), 35-44$.

Wennekers, S., \& Thurik, R. (1999). Linking entrepreneurship and economic growth. Small Business Economics, 13(1), 27-56.

Wennekers, S., Van Wennekers, A., Thurik, R., \& Reynolds, P. (2005). Nascent entrepreneurship and the level of economic development. Small Business Economics, 24(3), 293-309. 
Wilson, K. E., Vyakarnam, S., Volkmann, C., Mariotti, S., \& Rabuzzi, D. (2009). Educating the Next Wave of Entrepreneurs: Unlocking Entrepreneurial Capabilities to Meet the Global Challenges of the 21 st Century. A Report of the Global Education Initiative. Cologny, Geneva: World Economic Forum. Available at SSRN: http://dx.doi.org/10.2139/ssrn.1396704
Yukongdi, V., \& Lopa, N. Z. (2017). Entrepreneurial intention: a study of individual, situational and gender differences. Journal of Small Business and Enterprise Development, 24(2), 333-352.

Yurtkoru, E. S., Kuşcu, Z. K., \& Doğanay, A. (2014). Exploring the antecedents of entrepreneurial intention on Turkish university students. Procedia-Social and Behavioral Sciences, 150, 841-850. 